\title{
HUBUNGAN ANTARA MODEL PEMBELAJARAN PROBLEM BASED LEARNING DENGAN KEMAMPUAN BERPIKIR KRITIS PADA PEMBELAJARAN FISIKA SISWA
}

\author{
Nur Arifah ${ }^{1}$, Fitriani Kadir ${ }^{2}$, Harto Nuroso ${ }^{3}$ \\ ${ }^{1,3}$ Universitas PGRI Semarang, ${ }^{2}$ Universitas Muslim Maros \\ ${ }^{1}$ nurarifah85412@gmail.com, ${ }^{2}$ fktria85@umma.ac.id, ${ }^{3}$ hartonuroso@upgris.ac.id
}

\begin{abstract}
The Relationship Between Problem Based Learning Model and Critical Thinking Ability in High School Physics Learning. This study aims to analyze a relationship, the relationship between problem based learning (PBL) learning models and students' critical thinking skills in physics learning activities. The research method used is a meta-analysis with a sample of 10 articles in national journals and the instrument used is the Human Instrument. The results of the study indicate that there is a significant relationship between the problem based learning (PBL) learning model and students' critical thinking skills in physics learning activities. From the explanation above, so that the problem based learning (PBL) learning model has an influence on students on the ability to think critically in the learning activities of physics subjects.
\end{abstract}

Keywords: relationship, problem based learning, critical thinking

\begin{abstract}
Abstrak: Hubungan Antara Model Pembelajaran Problem Based Learning dengan Kemampuan Berpikir Kritis pada Pembelajaran Fisika SMA. Tujuan dari penelitian ini adalah menganalisis hubungan antara model pembelajaran problem based learning (PBL) dengan kemampuan berpikir kritis siswa pada pembelajaran fisika. Metode penelitian yang digunakan adalah meta-analisis dengan sampel sebanyak 10 artikel pada jurnal nasional dan instrument yang digunakan adalah Human Instrument. Hasil dari penelitian meta-analisis menunjukkan bahwa adanya hubungan yang signifikan antara model pembelajaran problem based learning (PBL) dengan kemampuan berpikir kritis siswa pada pembelajaran fisika. Dari hubungan tersebut maka model pembelajaran problem based learning (PBL) memberikan pengaruh secara signifikan terhadap kemampuan berpikir kritis siswa pada pembelajaran fisika.
\end{abstract}

Kata kunci: hubungan, problem based learning, kemampuan berpikir kritis

"Ilmu Fisika adalah suatu cabang ilmu dalam bidang sains, yang mempelajari terkait perubahan alam yang ada didalam kehidupan sehari-hari. Dengan itu interaksi-interaksinya dari perubahan alam tersebut, maka pada kegiatan pembelajaran fisika pendidik atau guru diharapkan dapat menumbuhkan minat belajar siswa serta meningkatkan motivasi dalam belajar 
agar siswa dengan mudah dapat berpikir kritis terkait konsep-konsep dalam fisika yang berkaitan erat pada kehidupan sehari-hari di lingkungan sekitar"(Izzah Al-Fikry, Yusrizal, 2018). "Critical thinking can be defined that thinking is not only about how someone can answer a question under certain conditions but also about how to get answers and solutions or new thoughts systematically and precisely. So the ability to think critically must be honed from an early age" (Mundilarto, 2017). Dari pernyataan diatas, sehingga definisi dari berpikir kritis adalah cara seseorang menjawab sebuah pertanyaan dengan sistematis dan tepat. Maka dari itu dengan berpikir kritis akan menjadikan siswa memiliki kecerdasan dalam berpikir terhadap lingkungan disekitarnya.

Dasar dalam kemampuan berpikir kritis mempunyai 3 aspek yaitu pernyataan, masalah dan argumen. Pernyataan merupakan langkah awal yang dilakukan dalam bertindak berpikir kritis pada suatu keadaan. Pernyataan tidak selalu dapat dikatakan benar atau salah, sehingga dalam pernyataan tidak perlu dievalusi secara kritis terkait benar dan salah. Adapun masalah adalah pertanyaan yang muncul yang selanjutnya dengan pertanyaan tersebut dapat menjawab pernyataan itu benar atau salah. Selanjutnya yang terakhir adalah argumen, argumen merupakan langkah akhir dalam berpikir kritis. Setelah adanya pernyataan dan pertanyaan lalu seorang siswa mampu merespon dan memberikan alasan yang mendasarkan pada pernyataan dan pertanyaan.

Dalam kegiatan pembelajaran fisika kecakapan siswa dalam berpikir kritis sangat diperlukan, karena dalam sebuah pembelajaran fisika mencakup teori-teori yang bersangkutan pada kondisi alam dan kehidupan. "Pada dasarnya dengan model pembelajaran dapat membimbing siswa untuk menemukan konsepkonsep dan melatih siswa dalam mengembangkan keterampilannya (Mufit, 2019). Model pembelajaran berperan sebagai pendukung kegiatan pembelajaran dan dapat mempengaruhi keberhasilan siswa dalam belajar (Mufit, 2018). Model pembelajaran berbasis masalah atau Problem Based Learning (PBL) mampu digunakan guru untuk mengembangkan keterampilan siswa dalam kemampuannya berpikir kritis dengan sebaik-baiknya"(Laura Aliyah Agnezi, 2020).

"Model pembelajaran Problem Based Learning $(P B L)$ atau model pembelajaran berbasis masalah yakni sebuah model pembelajaran yang dalam kegiatan pembelajarannya memfokuskan dan mengutamakan pada kegiatan bagaimana prosedur dalam pemecahan dari masalah"(Eka Yulianti, 2019). "Model pembelajaran Problem Based Learning (PBL) atau model pembelajaran berbasis masalah mampu mendukung siswa dalam meningkatkan kemampuan serta kecakapannya dalam berpikir kritis dan menyikapi serta mengatasi masalah dalam kehidupan dilingkungan sekitar, oleh karena itu menjadikan siswa lebih mudah memahami teori dan konsepsi fisika yang ada kaitannya dengan alam dan lingkungan di kehidupan"(Husnah, 2017).

"Menurut Sanjaya (2006:213) ada tiga hal yang mendasari pentingnya Problem Based Learning $(P B L)$ butuh adanya perbaikan dalam penerapannya dalam kegiatan pembelajaran. Pertama, berdasarkan pada aspek psikologi belajar siswa, Problem Based Learning (PBL) dalam aspek psikologi kognitif belajar merupakan proses berubahnya sebuah tingkah laku dikarenakan terdapat sebuah pengalaman atau wawasan yang sudah diketahuinya. Kedua, dalam aspek filosofis mengenai kedudukan makna sekolah yang digunakan sebagai tempat untuk menjadikan diri dan membangun diri siswa dalam kehidupan di masyarakat, maka Problem Based Learning (PBL) penting dikembangkan untuk memberi latihan dalam kemampuan siswa untuk memecahkan sebuah masalah yang akan dihadapinya dalam kehidupan. Ketiga, berdasarkan dalam konteks perbaikan terkait kualitas pendidikan, Problem Based Learning (PBL) mampu untuk merubah sistem pembelajaran, dan sudah kita ketahui bersama bahwa siswa untuk menyelesaikan serta menanggapi suatu masalah masih dalam keadaan kurang dan guru kurang memerhatikan dalam konteks ini."(Ikhwanul Muslim, A. Halim, 2015).

Berdasarkan pada uraian teori-teori di atas, dalam penelitian ini adalah peneliti akan menganalisis hubungan dari model pembelajaran Problem Based Learning (PBL) terhadap 
kemampuan berpikir kritis siswa. Dengan sintaks model pembelajaran Problem Based Learning (PBL) diantaranya adalah orientasi siswa terhadap masalah, mengorganisasikan siswa, membimbing secara individu maupun kelompok, mengembangkan dan mempresentasikan hasil diskusi serta menganalisa dan mengevaluasi proses pemecahan masalah. Dari sintaks tersebut maka peneliti akan menganalisis seberapa besar dampak penggunaan model pembelajaran Problem Based Learning (PBL) terhadap pemikiran siswa untuk menjadikan siswa mempunyai kemampuan berpikir kritis saat kegiatan pembelajaran fisika.

Penelitian terdahulu menurut Laura Aliyah Agnezi 2020, menyatakan bahwa penggunaan model pembelajaran Problem Based Learning $(P B L)$ dapat digunakan guru untuk mengembangkan keterampilan siswa dalam kemampuannya berpikir kritis dengan sebaikbaiknya dalam kegiatan pembelajaran. Menurut Eka Yulianti 2019, menyimpulkan bahwa pada model pembelajaran Problem Based Learning $(P B L)$ memfokuskan siswa untuk memecahkan masalahnya dengan mandiri sehingga dengan tindakan tersebut siswa akan terbiasa berpikir kritis dan mempunyai mempunyai kemampuan berpikir kritis tingkat tinggi.

Dari uraian yang sudah dipaparkan diatas sehingga peneliti menganalisis model pembelajaran yaitu terkait dengan Problem Based Learning (PBL) terhadap hubungan nya dengan meningkatkan skill siswa dalam kemampuan berpikir kritis, dengan judul dalam penelitian ini "Hubungan Antara Model Pembelajaran Problem Based Learning dengan Kemampuan Berpikir Kritis pada Pembelajaran Fisika SMA".

\section{METODE}

Dalam penelitian ini menggunakan metode meta-analisis. Dengan menggunakan metode meta-analisis, dalam pengumpulan datanya yaitu dengan dilakukannya proses mengkaji dan menganalisis beberapa artikelartikel pilihan yang terdapat pada jurnal nasional. Pencarian jurnal nasional dengan menggunakan Google Scholar. Metode metaanalisis bersifat kuantitatif karena dalam menyusun dan mengekstraksi (meringkas) suatu informasi data secara praktis dengan menggunakan perhitungan angka-angka dan statistik. Populasi dalam penelitian ini adalah dengan menggunakan artikel pada jurnal penelitian terdahulu yang diterbitkan secara online pada tahun 2010-2020 yang tersedia di Google Scholars tentang pengaruh atau hubungan antara model pembelajaran yaitu model pembelajaran Problem Based Learning dengan kemampuan berpikir kritis siswa pada pembelajaran fisika. Penelitian ini menggunakan 10 sampel artikel pada jurnal, jurnal tersebut diterbitkan pada tahun 2020 (sebanyak 2 jurnal), 2019 (sebanyak 1 jurnal), 2018 (sebanyak 2 jurnal), 2017 (sebanyak 2 jurnal), 2015 (sebanyak 1 jurnal), 2013 (sebanyak 1 jurnal) dan 2010 (sebanyak 1 jurnal). Kesepuluh jurnal tersebut bertemakan terkait hubungan model pembelajaran Problem Based Learning (PBL) terhadap kemampuan siswa berpikir kritis dalam kegiatan pembelajaran mata pelajaran fisika. Jurnal yang digunakan sebagai sampel adalah jurnal dengan sasarannya siswa SMA.

Instrumen dalam penelitian ini ialah dengan menggunakan instrument Human Instrument. Pengembangkan instrument yang dilakukan dalam penelitian ini dengan sederhana, dengan itu mampu melengkapi data yang telah didapatkan. Teknik dalam analisis data pada penelitian ini adalah dengan prosedur membandingkan nilai effect size dengan kriteria ukuran nilai effect size. Teknik tersebut digunakan untuk menentukan kategori besarnya hubungan model pembelajran Problem Based Learning (PBL) pada kecakapan atau kemampuan siswa dalam berpikir kritis di pembelajaran fisika.

Analisis deskriptif adalah analisis yang digunakan dalam teknik analisis data dalam penelitian ini, dengan melakukan perhitungan sebuah nilai effect size dari jumlah nilai rata-rata pada pretest (penilaian sebelum kegiatan pembelajaran) dan posttest (penilaian setelah kegiatan pembelajaran). Effect size berperan penting dalam menunjukkan nilai efisiensi siswa dalam kemampuan berpikir kritis tersebut setelah dilakukannya penerapan proses pembelajaran fisika dengan model pembelajaran Problem Based Learning (PBL). Prosedur dalam penelitian adalah dengan melakukan pengolahan 
Karst : Jurnal Pendidikan Fisika dan Terapannya Volume 4 | Nomor $1 \mid 17$ p-ISSN: 2622-9641 e-ISSN: 2655-1276

semua data-data di penelitian ini diantaranya: 1) mencatat variabel penelitian, lalu dimasukan ke dalam tabel, 2) mencatat rata-rata pretest dan postest untuk setiap subjek penelitian, 3) menghitung nilai effect size, nilai effect size dihitung dengan menggunakan persamaan berikut (Glass, 1976):

$$
E S=\bar{\Delta}=\frac{\overline{X_{e}}-\overline{X_{c}}}{S c}
$$

Keterangan:

ES : Effect Size

$\mathrm{Xe} \quad$ : Nilai rerata kelompok posttest

Xc : Nilai rerata kelompok pretest

Sc : Nilai impangan baku kelompok pretest

Dengan kriteria ukuran nilai effect size pada tabel 1:

Tabel 1. Kriteria Interpretasi Effect Size Cohen's

\begin{tabular}{ll}
\hline Effect Size & Deskripsi Verbal \\
\hline $0,2 \leq \mathrm{p}<0,5$ & Kecil \\
$0,5 \leq \mathrm{p}<0,8$ & Sedang \\
$0,8 \leq \mathrm{p}<2,0$ & Besar \\
\hline
\end{tabular}

\section{HASIL DAN PEMBAHASAN}

Mengikuti pada hasil sebuah penelitian ini yang dilaksanakan penelitiannya dengan mengkaji serta menganalisis 10 artikel pada jurnal. Maka peneliti dapat mengumpulkan banyak data terkait dengan model pembelajaran yang digunakan yaitu Problem Based Learning $(P B L)$ terhadap kemampuan peserta didik dalam berpikir kritis pada pembelajaran fisika. Salah satu data yang ada dalam penelitian ini adalah berupa nilai rata-rata pada sebelum tindakan penggunaan model pembelajaran Problem Based Learning (PBL) (pretest) dan sesudah tindakan atau setelah kegiatan pembelajaran (posttest), nilai rata-rata tersebut dalam bentuk penskoran. Melalui kegiatan mengkaji dan menganalisis artikel pada jurnal diketahui beberapa data, yang kemudian data tersebut dianalisis dengan menggunakan teknik analisis deskriptif. Teknik analisis data dengan menghitung nilai effect size berdasarkan pada nilai rata-rata pretest dan postest.

Berdasarkan hasil analisis yang telah dilakukan, diperoleh effect size dari 10 sampel artikel pada jurnal dan disertai dengan kategori yang mengacu pada nilai effect size tersebut, untuk hasil analisis tertera pada Tabel 2 yaitu sebagai berikut:

Tabel 2. Hasil Analisis Effect Size Nilai Rerata Pretest dan Posttest

\begin{tabular}{cccccc}
\hline No. & Jurnal & Pretest & Posttest & Effect Size & Kategori \\
\hline 1. & J1 & 59,42 & 65,52 & 1,49 & Besar \\
2. & J2 & 60,32 & 67,54 & 1,76 & Besar \\
3. & J3 & 66,44 & 73,65 & 1,76 & Besar \\
4. & J4 & 61,34 & 68,33 & 1,70 & Besar \\
5. & J5 & 69,12 & 76,65 & 1,84 & Besar \\
6. & J6 & 63,22 & 70,45 & 1,76 & Besar \\
7. & J7 & 61,41 & 69,12 & 1,88 & Besar \\
8. & J8 & 62,33 & 70,34 & 1,95 & Besar \\
9. & J9 & 71,88 & 75,72 & 0,93 & Besar \\
10. & J10 & 66,30 & 73,21 & 1,68 & Besar \\
\hline
\end{tabular}

Dari tabel 2 tersebut, dapat disimpulkan bahwa nilai effect size pada jurnal 1 dengan nilai pretest 59,42 dan nilai posttest 65,52 adalah sebesar 1,49. Pada jurnal 2 dengan nilai pretest 60,32 dan nilai posttest 67,54 diketahui nilai effect size sebesar 1,49. Pada jurnal 3 dengan 
nilai pretest 66,44 dan nilai posttest 73,65 diketahui nilai effect size sebesar 1,76. Pada jurnal 4 dengan nilai pretest 61,34 dan nilai posttest 68,33 diketahui nilai effect size sebesar 1,70. Pada jurnal 5 dengan nilai pretest 69,12 dan nilai posttest 76,65 diketahui nilai effect size sebesar 1,84. Pada jurnal 6 dengan nilai pretest 63,22 dan nilai posttest 70,45 diketahui nilai effect size sebesar 1,76. Pada jurnal 7 dengan nilai pretest 61,41 dan nilai posttest 69,12 diketahui nilai effect size sebesar 1,88. Pada jurnal 8 dengan nilai pretest 62,33 dan nilai posttest 70,34 diketahui nilai effect size sebesar 1,95. Pada jurnal 9 dengan nilai pretest 71,88 dan nilai posttest 75,72 diketahui nilai effect size sebesar 0,93. Pada jurnal 10 dengan nilai pretest 66,30 dan nilai posttest 73,21 diketahui nilai effect size sebesar 1,68.

Dari hasil analisis pada effect size dapat disimpulkan bahwa 10 artikel pada jurnal mempunyai kriteria ukuran nilai effect size dengan deskripsi variable besar.

\section{PEMBAHASAN}

Penelitian yang dilakuan dengan subjek penelitian adalah artikel pada jurnal diperoleh dengan cara menelusuri artikel-artikel online dengan menggunakan Google Scholar. Setelah menelusuri beberapa artikel pada jurnal tersebut didapatkan 10 jurnal nasional yang relevan. Selanjutnya menganalisis dan mengkaji pada tiap jurnal yang diperoleh. Hal yang menjadi fokus utama dalam menganalisis jurnal adalah isi, hasil, kelebihan, kekurangan, saran dan data dari sebelum tindakan (pretest) dan sesudah tindakan (posttest) dalam bentuk penskoran.

Dari data nilai rerata sebelum tindakan (pretest) dan (sesudah tindakan) posttest pada setiap jurnal diperoleh nilai effect size dan kriteria ukuran nilai effect size pada tiap jurnal. Nilai effect size dan kriteria ukuran nilai effect size dapat diperhatikan di tabel 2. Berdasarkan yang tertulis di tabel 2 bahwa hasil nilai effect size tertinggi dimiliki oleh jurnal J8 sebesar 1,95 dengan kriteria ukuran nilai effect size besar sedangkan untuk nilai terendah dimiliki oleh jurnal J9 sebesar 0,93 dengan kriteria ukuran nilai effect size besar. Rata-rata nilai effect size yang diperolah dari 10 jurnal adalah sebesar 1,67 dengan kategori besar.
Hasil nilai effect size yang didapatkan an tertulis di tabel 2 menunjukkan bahwa rerata nilai gain yang diperoleh dari 10 jurnal adalah 1,67 dengan kriteria ukuran nilai effect size besar. Hal ini menunjukkan bahwa kemampuan siswa dalam berpikir kritis pada pembelajaran fisika mengalami peningkatan dengan diterapkan model pembelajarn Problem Based Learning pada kegiatan pembelajaran, dan dari nilai nilai gain tersebut untuk kriteria ukuran nilai effect size dengan deskripsi variable besar.

Dalam mengkaji beberapa artikel peneliti terdahulu menyimpulkan antara model pembelajarn Problem Based Learning dengan kemampuan berpikir kritis terdapat hubungan secara signifikan. "Dalam sebuah model pembelajaran terdapat beberapa perbedaan secara fisis, perbedaan tersebut terlihat pada output siswa dalam kemampuan berpikir kritis. Dan model pembelajaran yang dapat memberikan peningkatan skill dalam kemampuan berpikir kritis siswa adalah model pembelajaran Problem Based Learning (PBL) atau model pembelajaran berbasis masalah "(Ni Luh Putu Sunariyati, Anak Agung Gede Agung, 2014). "Setelah melalui beberapa tahapan kegiatan pembelajaran dengan model pembelajaran Problem Based Learning (PBL) hasilnya ialah terjadinya proses meningkatkan kemampuan siswa dalam kemampuan berpikir kritis dalam diri siswa"(Nur Azizah, Siska Desy Fatmaryanti, 2014). “ Dari sekian banyaknya model pembelajaran yang ada terdapat satu model pembelajaran yang dirasa dengan model tersebut mampu merubah siswa dalam hal menumbuhkan keterampilan dan kecapakannya dalam berpikir kritis siswa (penalaran, komunikasi dan koneksi) dalam menyelesaikan dan menyikapi sebuah masalah adalah model pembelajaran Problem Based Learning (PBL). Dalam model pembelajaran Problem Based Learning $(P B L)$ itu dirasa sangat penting dalam menggunakan kecerdasan yang digunakan untuk menghadapi masalah atau tantangan dalam dunia nyata, kecakapan untuk menghadapi segala sesuatu yang baru dan kompleksitas yang ada"(Restu Fristadi, 2015). "Respon siswa dan suasana kelas menjadi lebih kondusif dan mendukung peningkatan kemampuan berpikir kritisitu merupakan hasil dalam penggunaan model pembelajaran Problem Based Learning 
(PBL)."'(Laksmiwati \& Khoirunnisa, 2018). "Pengajaran pada model pembelajaran Problem Based Learning (PBL) berdasarkan pada suatu masalah sehingga siswa mampu memecahkan permasalahan, yang permasalahannya itu merupakan permasalahan yang otentik dengan maksud dan tujuan khusus untuk menyusun an menumbuhkan pengetahuan siswa, mengembangkan kembali inkuiri dan meningkatkan keterampilan tingkat tinggi, serta mengembangkan kemandirian dan percaya diri”(R Diani, 2016).

Dari hasil penelitian dan pernyataanpernyataan peneliti terdahulu sehingga bisa ditarik kesimpulan maka dengan memakai model pembelajaran berbasis masalah atau Problem Based Learning (PBL) pada pembelajaran fisika mampu meningkatkan kemampuan atau kecakapan dan keterampilan siswa dalam berpikir kritis. Serta dari hasil perhitungan pada keseluruhan effect size diperoleh dari 10 jurnal adalah 1,67 dengan kriteria ukuran nilai effect size besar.

\section{PENUTUP}

Menurut dari semua cakupan yang terdapat pada hasil dan pembahasan di atas dalam penelitian ini, sehingga kesimpulan yang dapat diutarakan pada penelitian kali ini yakni sebagai berikut.

Bahwa dengan penerapan model pembelajaran Problem Based Learning (PBL) mampu memberikan berpengaruh tinggi dalam meningkatkan dan mengembangkan keterampilan berpikir kritis siswa pada pembelajaran fisika.

Dari perhitungan yang dilakukan dengan menggunakan rumus effect size pada rumus perbandingan Glass, dihasilkan rerata dari nilai effect size dengan dikategorikan besar. Hal ini

\section{DAFTAR PUSTAKA}

Eka Yulianti, I. G. (2019). Model Pembelajaran berbasis masalah/Problem Based Learning $(P B L)$ : Dampaknya Atas Pemahaman pada Konsep Dan Berpikir Kritis. Indonesian Journal of Science and Mathematics Education, 02(3), 399-408. menunjukkan bahwa dengan penerapan model pembelajaran Problem Based Learning (PBL) pada pembelajaran fisika siswa berperan besar dalam meningkatkan kemampuan siswa dalam kemampuan berpikir kritis.

Jadi model pembelajaran Problem Based Learning $(P B L)$ yang diterapkan dalam kegiatan pembelajaran dapat menjadi acuan untuk para pendidik pada melaksanakan kegiatan pembelajaran, dengan tujuan khusus untuk menumbuhkan serta meningkatkan kemampuan berpikir kritis siswa pada pembelajaran fisika. "Beberapa peneliti memberikan masukan dalam menerapkan suatu model pembelajaran yaitu model pembelajaran berbasis masalah atau Problem Based Learning (PBL) selayaknya meninjau dari beberapa hal diantaranya kesesuaian materi, karena dalam pelaksanaannya model ini dibutuhkan durasi waktu yang relative panjang atau lama"(Laksmiwati \& Khoirunnisa, 2018).

Tindak lanjut dari penelitian ini adalah upaya meningkatkan kemampuan berpikir kritis siswa SMA terhadap pembelajaran fisika dengan penerapan model pembelajaran Problem Based Learning $(P B L)$ dapat ditingkatkan. Maka dari itu, peneliti merencanakan akan menerapkan model pembelajaran Problem Based Learning $(P B L)$ dalam proses pembelajaran fisika selanjutnya. Rencana tindak lanjut penerapan model pembelajaran Problem Based Learning $(P B L)$ tidak hanya sebatas meningkatkan kemampuan berpikir kritis saja, namun akan diterapkan pada siswa agar materi fisika yang diberikan oleh guru mudah diterima oleh siswa karena dengan model pembelajaran Problem Based Learning (PBL) pembelajaran berpusat pada siswa dan dapat mengendap dalam ingatan lebih cepat, sehingga siswa lebih cepat hafal serta siswa mampu memahamo materi fisika tersebut dengan baik.

Husnah, M. (2017). Hubungan Tingkat Berpikir Kritis Terhadap Hasil Belajar Fisika Siswa Dengan Menerapkan Model Pembelajaran Problem Based Learning. Journal of Physics and Science Learning (PASCAL), 01(2), 1017. 
Ikhwanul Muslim, A. Halim, R. S. (2015). Penerapan Model Pembelajaran PBL untuk Meningkatkan Penguasaan Konsep dan Keterampilan Berpikir Kritis Siswa pada Konsep Elastisitas dan Hukum Hooke di SMA Negeri Unggul Harapan Persada. Jurnal Pendidikan Sains Indonesia, 03(02), 35-50.

Izzah Al-Fikry, Yusrizal, dan M. S. (2018). Pengaruh Model Problem Based Learning Terhadap Kemampuan Berpikir Kritis Peserta Didik Pada Materi Kalor. Jurnal Pendidikan Sains Indonesia (Indonesian Journal of Science Education), 6(1), 17-23.

Laksmiwati, Y. W. S. H., \& Khoirunnisa, R. N. (2018). Penerapan Model Problem Based Learning untuk Meningkatkan Kemampuan Berfikir Kritis Mahasiswa. Jurnal Pendidikan (Teori Dan Praktik), 3(1), 7.

Laura Aliyah Agnezi, S. R. (2020). Meta Analisis Pengaruh Model Problem Based Learning Terhadap Kemampuan Berpikir Kritis Siswa. Jurnal Penelitian Dan Pembelajaran Fisika, 6(2), 136-145.

Mundilarto, H. I. (2017). Effect of Problem-Based Learning on Improvement Physics Achievement and Critical Thinking of Senior High School Student. Journal of Baltic Science Education, 16(5), 761-780.
Ni Luh Putu Sunariyati, Anak Agung Gede Agung, N. D. (2014). Pengaruh Model Pembelajaran Berbasis Masalah (Problem Based Learning/Pbl) Terhadap Hasil Belajar, Keterampilan Berfikir Kritis Dan Sikap Ilmiah Dalam Pembelajaran Fisika Pada Siswa Kelas XI IPA Sma Negeri 1 Kuta Tahun Pelajaran 2014/2015. 1-7.

Nur Azizah, Siska Desy Fatmaryanti, N. N. (2014). Penerapan Model Pembelajaran Konstruktivisme Berbasis Problem Based Learning ( $P B L$ ) Untuk Meningkatkan Kemampuan Berfikir Kritis Pada Siswa SMA Negeri 1 Kutowinangun Kelas $X$ Tahun Pelajaran 2013 / 2014. Radiasi, 5(2), 24-27.

R Diani, A. S. dan A. I. (2016). Perbandingan Model Pembelajaran Problem Based Learning dan Inkuiri Terbimbing Terhadap Kemampuan Berpikir Kritis Peserta Didik. Jurnal Penelitian Pembelajaran Fisika, 7(2), 147155.

Restu Fristadi, H. B. (2015). Meningkatkan Kemampuan Berpikir Kritis Siswa Dengan Problem Based Learning. Seminar Nasional Matematika Dan Pendidikan Matematika UNY, 597-602. 